\title{
AMPLIFIED VULNERABILITIES AND RECONFIGURED RELATIONS: COVID-19, TORTURE PREVENTION AND HUMAN RIGHTS IN THE GLOBAL SOUTH ${ }^{1}$
}

\author{
Andrew M. Jefferson, Giorgio Caracciolo, \\ Jeanette Kørner and Nina Nordberg
}

\begin{abstract}
The COVID-19 pandemic has reconfigured personal, organisational and political landscapes in quite radical ways. This paper reflects on the differentiated impact of the COVID-19 pandemic and responses to it. We unpack some of the effects of the crisis on populations already subject to harassment, persecution and deprivation due to their marginal position in society or their resistance to state power. We illuminate how the current crisis is much more than a health crisis; the ways it exacerbates already existing deprivations; and how it might reveal hitherto unrecognised opportunities through which to make the world a more, rather than less, just and equitable place. Focus is on the way the crisis calls forth amplified forms of repression and consonantly amplified forms of vulnerability as well as reconfigured spaces for the operation of civil society organisations. We forward one key proposition, namely that while securitised responses to the crisis reveal an inherent conservatism, civil society responses reveal an agility and a capacity to innovate. While the inherent conservatism of securitised responses gives cause for serious concern, there is some hope to be found in the potential for innovation of civil society organisations. The revelation of humankind's shared vulnerability that is a feature of the crisis may serve as a springboard for the propagation of progressive change if we keep in mind the fundamentally human, and thus relational, nature of human rights and anti-torture work.
\end{abstract}

Keywords: COVID-19; vulnerability; exacerbation; violence; civil society organisations

\section{Introduction}

The spread of COVID-19 in early 2020 shocked the world. Unlike Ebola (between 2014 and 2016), which, while fiercer and more deadly, was relatively contained,

Andrew M. Jefferson is a Senior Researcher at DIGNITY - Danish Institute Against Torture.

Giorgio Caracciolo is Senior Regional Manager for the Middle East and North Africa at DIGNITY. Jeanette Kørner is Senior Regional Manager for Africa and Latin America at DIGNITY.

Nina Nordberg is Senior Regional Manager for Asia and Eastern Europe at DIGNITY.

Produced and distributed by Pluto Journals www.plutojournals.com/scj/ 
COVID-19 spread more widely. This global pandemic serves as a temporal marker, a pivot around which people may even eventually orient personal and national histories. It is already reconfiguring personal and political landscapes. The acuteness of the crisis, its longevity, its global reach and heavy mediatisation as well as the apparent risk to all and sundry make this an unusual crisis. At the time of writing in August 2020 much remains uncertain. What we do know is that while the scientists are modelling as best they can, and the politicians are taking decisions against somewhat hazy backdrops, the life conditions of people living in poverty with violence as a backdrop are worsening.

The current and ongoing COVID-19 crisis, we shall argue, has exacerbated and still exacerbates already existing dynamics of human suffering and by doing so reminds all of us of the fundamental vulnerability of the human condition. Some people don't need reminding. They cannot forget. They live with such knowledge as an embedded everyday reality, either because of the indelible marks left on their bodies and spirits by violence, or the constant threat of harassment, intimidation and abuse, or the mundane experiences of life on the move, in flight or in exile. This paper is about the effects of the COVID-19 crisis on such populations.

We work at DIGNITY, a non-governmental organisation (NGO) based in Denmark but working globally (through partnerships with civil society organisations and state actors), to reduce torture and support people dealing with the aftermath of violence and trauma. DIGNITY can be characterised as a rights-oriented, knowledge-based, development organisation aspiring to make the most of insights learned through research and practice to prevent torture and alleviate its effects. Our own professional profiles, roles and experience within the organisation cover a wide range of national contexts and a variety of types of practical initiatives aimed at preventing torture and inhumane treatment, supporting survivors and understanding torture's toxic dynamics through academic research. As a group of authors, we represent a coming together of normatively oriented experience (that is involvement in practices designed to change the world) and understanding oriented experience (that is involvement in practices designed to make sense of the world). We understand this coming together not as the linking of separate spheres (e.g. theory and practice) but a mingling of experiences with slightly different orientations and points of departure. From this perspective we seek to shed some light on the way COVID-19 has played out in countries in which DIGNITY has been working over recent years.

We unpack some of the effects of the crisis on populations already at risk and subject to varying degrees of harassment, persecution and deprivation due either to their marginal position in society or their resistance to state power or a combination of the two. We illuminate how the current crisis is much more than a health crisis; the ways it exacerbates already existing deprivations; and perhaps - maybe against all the odds - how it might reveal hitherto unrecognised opportunities through 
which to make the world a more, rather than less, just and equitable place. Focus is on the way the crisis calls forth: a) amplified forms of repression and consonantly amplified forms of vulnerability; and b) reconfigured spaces for the operation of civil society organisations (CSOs) - some conducive some inhibiting.

As a result of our analysis we forward one key proposition, namely that while securitised responses to the crisis reveal an inherent conservatism (essentially more of the same), civil society responses reveal an agility and a capacity to innovate (essentially to reinvent themselves). While the inherent conservatism of securitised responses that contributes to making situations worse for at-risk populations gives cause for serious concern, there is some hope to be found in the potential for innovation of CSOs. The revelation of humankind's shared vulnerability that is a feature of the crisis may, we suggest, serve as a springboard for the propagation of progressive change.

Complex political emergencies are better approached and understood, argues Mark Duffield (2001), as emergent political complexes. The former is a term that might be readily applied to the recent and ongoing crisis of COVID-19. Faced with a virus with global reach and uncertain trajectory the world's political actorsgovernments, advisory agencies, UN bodies, spokespersons, advisors and so onreacted in a range of ways, at a range of speeds and with varying levels of acceptance or denial to an unfolding emergency. At some levels the pandemic can be conceived of as a simple emergency - an existential threat, a risk to lives and wellbeing, a basic issue of health. But as the crisis unfolded and responses to it developed piecemeal, and then as an avalanche of lockdowns, border controls, quarantine regimes, rafts of regulations and enforcement mechanisms, and political leaders and their health advisors fought for credibility and legitimacy in the eyes of an anxious public (sometimes in competition with one another), the complexity of the situation has become clear. The emergency's complexity was exacerbated by its novelty, its early exponential growth, its unknown potential (i.e. the threat of the virus to overpower existing capacity to deal with it) and the lack of a known cure.

It is these very complexities that point towards the utility of Duffield's notion of the emergent political complex as a way of analytically approaching what has been happening and is still going on. Health crises are of course nothing new. Neither are tensions between political leaders and their expert advisors or solutions to crises that lean on confining logics and securitising rationales. The fraught politics of health and health provision are well known and the idea and practice of confinement as a means of dealing with insecurity and fear of the unknown other is commonplace in western and non-western societies. Similarly, controversies and contestation around borders and mobility, the differential effects of crises on vulnerable populations, and the use of security forces to enforce restrictions are nothing exceptional. ${ }^{2}$ What may be new are the constellations and reconfigurations of 
political power and authority apparently warranted and justified by the crisis, and perhaps also the cracks in the edifices of power that have been revealed.

Doubt is a constituent feature of the crisis, not a product of it. Political leaders are having to make decisions on the fly with only experimental modelling to guide their decisions and a heavy weight of expectation on their shoulders. It is a situation with truly high stakes with both immediate and long-term deleterious effects on societies, economies, livelihoods, families and future global relations. It is an emergent crisis in the sense that consequences remain unclear and were unpredicted. It is a political crisis in the sense that contestations around power and authority and the relation between states and subjects (and states and civil society) are directly affected by the spread of the virus and by responses to it. And it can be thought of as a "complex" because of the presence of a set of interlinked, mutually dependent dynamics and assemblages that contribute to frame and give meaning to policies, practices and people's everyday experience.

Our experience-driven impressionistic review, informed in part by information provided by DIGNITY's partners in the course of our ongoing collaborations, in part by analysis of news stories and human rights reports, reminds us of the precarity of the lives of the core beneficiaries of DIGNITY's work. For people affected by torture, violence, war, poverty, marginalisation, displacement, flight, confinement, exile, stigmatisation and so on, the consequences of a crisis of this nature with its unpredictability, scope and magnitude are an unwelcome intrusion and amplification of pre-existing problems of survival. We recognise the potential of the crisis to be exploited to nefarious ends intentionally or by default, in the short and longer term. And we emphasise the value of trust, and the necessity of not taking for granted but strengthening institutional and interpersonal bonds of solidarity between local and international actors.

The countries that feature are Egypt, Kenya, South Africa, Uganda and the Philippines. Given this limited range of settings we cannot of course claim to offer an exhaustive overview. Rather, through paying attention to unfolding events and responses in these places we hope to identify concerns, puzzles and opportunities that might also have resonance in other contexts. Our insights offer a snapshot of particular places at a particular time during a still unravelling emergency, the effects of which all reliable commentators recognise will be with us for a long time to come.

\section{Country contexts}

\section{The Philippines}

Human rights standards in the Philippines have been eroding for the past four years under President Duterte with the civic space gradually shrinking. The latest 
development is the introduction of a sweeping anti-terrorism bill passed by both houses of Congress that came into force on July 3, 2020. Its critics argue that its broad interpretation of terrorism will allow the government to classify opponents/ critics/media personalities/civil society activists etc. as terrorists and detain them without a warrant for up to 24 days, thus silencing all kinds of dissent.

The first case of COVID-19 was found on January 30; from February social distancing was enforced; from April the government threatened the return of martial law style enforcement. On March 8, a state of public health emergency was declared. A week later, a so-called "enhanced community quarantine" (ECQ) — a de facto shutdown - was imposed in the metropolitan region, Metro Manila. It was later expanded to the largest of the country's three regions, Luzon, where over half of the country's population lives, many of them in densely populated poor neighbourhoods. By the end of April, 120,000 had been arrested for violating lockdown rules. The ECQ was lifted on June 21 and replaced by the GCQ (general community quarantine) that allow local government units (LGUs) to impose local restrictions. With COVID-19 numbers surging once again, lockdown was reintroduced in Manila and four surrounding provinces for two weeks as of August 4, 2020 ("Modified ECQ").

\section{Egypt}

Since 2013, following the heady hopeful days of the Arab Spring, there has been a heavy clampdown in Egypt. Types of figures subject to repression include members of the political opposition, human rights defenders, LGBTIQ+ people and activists, pro-democracy university teachers (for example those who publish about the need to preserve democratic values), journalists, doctors who speak out (Devi 2020) and so on. It has been the feeling among pro-democracy and human rights activists for some time that the human rights situation in Egypt cannot get any worse. And yet it has continued to do just that and COVID-19 is yet another driver of this tragic development. There has been no national lock down due to the disastrous economic situation. Compared to other neighbouring countries, Egypt seems to have fared relatively badly under COVID-19. Emergency legislation was pushed through-like in many countries. Organisations such as Human Rights Watch, Amnesty International and DIGNITY's partner, the Committee for Justice, criticised the legislation, seeing it as overreach in the absence of lockdown (Human Rights Watch 2020a).

The first case of COVID-19 was detected in Egypt on February 14. There were growing cases in March, and on March 22 the government closed all mosques for two weeks and suspended all flights. From March 25 a curfew was put in place. Restrictions started easing from July 1. Prisons were isolated and remain closed to visitors at the time of writing. Absurdly, while tourists are welcome to Sharm El 
Sheik without any limitations or obligations of quarantine, prisoners are still prevented from having visits. While there was no formal lockdown, some professionals sought to limit social contact to protect themselves and others but not everyone is able to take such action.

\section{South Africa}

Torture and violence in South Africa are largely associated with apartheid-era violations of human rights, where the most visible targets were liberation struggle stalwarts. But torture and violence did not cease with the demise of apartheid; it took on new forms. Today, victims of torture are not those fighting against the oppression of white rule but those on the fringes of society, for example refugees, political and commercial migrants, commercial sex workers, members of the LGBTIQ+ community, persons criminalised by poverty and people in the wrong place at the wrong time.

The first case of COVID-19 was detected on March 1, and on March 15, 2020 the president declared a national state of disaster. Lockdown measures came into effect in the beginning of April. In May the government banned sales of alcohol and introduced a curfew, both of which were eased in June and reintroduced in July following a resurgence. The enforcement of emergency regulations was the duty of the police, supported by the South African National Defense Forces through the mobilisation of close to 3,000 soldiers. Within the first seven days of lockdown, security forces had arrested more than 2,000 people for quarantinerelated breaches.

\section{Uganda}

Uganda has been ruled by President Museveni since 1986. A long-running conflict between the government and insurgents in the north, which received considerable attention from media and human rights activists due to atrocities committed on both sides, seemed to fizzle out around 2017 when the army at least declared the insurgents a spent force. Today, the rights landscape is dominated by concerns over freedom of expression, the reduction of space for political opposition, and the treatment of members of LGBTIQ+ communities in a country where same-sex relationships were criminalised in 2014.

The first COVID-19 case was detected at the beginning of March, with lockdown restrictions from March 18, including churches, public meetings, restaurants and so on. Foreigners and Ugandans arriving in the country were subject to 14 days of quarantine. Furthermore, all public transport was suspended. As in South Africa, the Ugandan government has deployed national armed forces to ensure enforcement of the restrictions, which has led to an increase in violence against citizens, bringing back memories of the country's violent and conflicted past. 


\section{Kenya}

Kenya is a conflicted country. In 2013 the first elections under a new constitution (of 2010) resulted in the son of Kenya's first post-independence president taking over the presidency. Both the elections of 2007 and 2017 were fraught and fractious affairs with much violence and contestation. Human rights actors draw attention to the lack of accountability for abuses committed by the police and security forces against land rights activists, forest dwellers and the urban poor and the hostile climate for journalists. Echoes of the murderously harsh tactics of the British against the Mau Mau uprising in the 1950s can be discerned in the way security forces deal with opposition. ${ }^{3}$

The first COVID-19 case was detected on March 13, and from March 15 travel from COVID-19 affected countries was restricted, travel-related quarantine implemented, and offices, schools, churches and government institutions closed. In June travel restrictions were extended to include travel to and from the countryside to metropolitan areas.

\section{What We Do in the Countries, Who We Work With and Who We Work For}

In the Philippines DIGNITY is working with Balay and Childrens' Legal Rights and Development Center (CLRDC) (see www.dignity.dk.). The work is with prison and jail authorities, prisoners, and children in conflict with the law in very poor, deprived neighbourhoods. The latter populations constitute the "poorest of the poor", those at the bottom of the socio-economic ladder who have always bore the brunt of violence, both committed by state or non-state actors.

In Egypt DIGNITY supports CSOs like Committee for Justice (CFJ) (and others we choose not to name because of security concerns) with the aim of securing their presence and enabling them to address severe human rights violations like torture and enforced disappearance, and document, report and engage in advocacy and national dialogue to establish protective grids around victims and human rights defenders. DIGNITY's role is to speak of the work of local activists at the international level; engage in joint UN advocacy, coalition creating, building capacity where appropriate, bridging between Egyptian partners and other international actors and basically being as helpful as possible.

In South Africa DIGNITY works with the Centre for the Study of Violence and Reconciliation (CSVR) to provide highly specialised mental health and psychosocial services (MHPSS) to survivors of torture and violence in clinics in Johannesburg, Pretoria and Cape Town, and offer psychological support and counselling to survivors of torture and violence in the local communities of Marikana. 
In Uganda DIGNITY works with the African Centre for Treatment and Rehabilitation of Torture Victims (ACTV) to provide access to trauma-informed MHPSS and raise awareness on torture, trauma and existing service provision in the local communities of Kasese, with the purpose of changing attitudes and practices towards trauma-affected survivors, promoting help-seeking behaviour and increasing referrals of survivors by first responders.

In Kenya, DIGNITY works with Midrift-Hurinet to prevent violence in urban informal settlements and provide psychosocial support to survivors of violence through a community approach, especially to survivors of genderbased violence (GBV).

We turn now to consider the various ways in which COVID-19 has exacerbated pre-existing vulnerabilities.

\section{Amplification and Compression}

In this section we present a range of examples about how pre-existing dynamics of vulnerability and inequality have been reinforced by COVID-19 and responses to it. We do so under the heading amplification and compression to capture something of the way poor conditions of life are enhanced in ways that crush, restrict and shrink possibilities. We know that confinement and other restrictions on liberty tend to exacerbate pre-existing deprivations, that the effects of a crisis are never experienced equally (see Jefferson 2017). What we are considering here is what happens when an acute crisis hits a chronic crisis.

One crude way the crisis has worsened the situation of already at-risk populations is by dominating the agenda and attracting all the attention. The preoccupation with the immediateness of the COVID-19 emergency contributes to a silence and lack of attention or scrutiny around other societal problems. In June, for example, Hodal (2020) in The Guardian reported on a rise in cases of female genital mutilation (FGM) and GBV in Egypt. Restrictions designed to protect create new vulnerabilities. In this case, the closure of schools removed part of the protective grid that served to inhibit the practice of FGM.

The crisis both distracts and focuses attention. A report by Al Jazeera (2020a), for example, notes the way the pandemic exposes "brutal inequalities" in South Africa in relation to housing and health that play out along racial lines. This is hardly new, but it is brought into sharp relief by the pandemic. Writing about Africa as a whole, Mogoatlhe (2020) observes the escalation of pre-existing problems noting three key areas: police heavy-handedness in enforcement, GBV and increased risk to marginalised groups. This resonates with our experience, though in the following section we also cover the policing of dissent and the promise of decarceration. 


\section{Increased Risk to Marginalised Populations}

\section{LGBTIQ+}

Both The Guardian (McCool 2020) and Human Rights Watch (Ghoshal 2020) report on violence meted out to members of the LGBTIQ+ community gathered in a homeless shelter in Uganda, where the pretext for their arrest and maltreatment is COVID-19-related restrictions but where the real reason is more likely rooted in pre-existing prejudicial and homophobic policies and policing practices. The pretext of enforcing restrictions disguises a pattern of harassment and intimidation targeting members of these communities.

\section{Migrants and Refugees}

In South Africa migrants and refugees are a core target population for CSVR's work to alleviate the effects of violence and trauma. In Johannesburg CSVR observed the negative consequences for migrants, refugees and displaced people that involved a profound impact on mental health. Their already precarious existence has been worsened by loss of income, food shortages, frustrations, fear and anger. The government response to the reduced opportunities imposed by lockdown was to provide food parcels but only to nationals, leaving foreigners (e.g. migrants and refugees) with little extra help and with casual labour opportunities lost (a helpline was called predominantly by non-South Africans). There has been an enhanced military presence on the streets, and strict and brutal enforcement of restrictions and curfews.

\section{Women}

It did not take long before alert agencies concerned with GBV all around the world predicted that lockdown initiatives would result in surges of domestic violence. DIGNITY's partners in South Africa and Kenya were particularly attentive to this development.

Media sources looking at South Africa made links between a ban on alcohol sales and decrease in crime; noting also a rise in the killing of women when restrictions were lifted (Harrisberg 2020a). In this connection South Africa's president was reported as saying: "[a]t a time when the pandemic has left us all feeling vulnerable and uncertain, violence is being unleashed on women and children with a brutality that defies comprehension" (Crabtree 2020). This lament contrasts with the bombastic rhetoric of Duterte in the Philippines and the security-oriented policies of Sisi in Egypt.

In the immediate COVID-19 situation there was a fear that police violence and GBV would increase in South Africa and Kenya. And it did. In South Africa the 
number of calls to a helpline increased significantly compared with the same period last year. A preliminary report released by the Gender-Based Violence Command Centre shows that while the number of reported crimes significantly dropped at the beginning of the lockdown, the number of incidents of GBV remained alarmingly high, with more than 12,000 cases reported since the start of the national lockdown on March 27, 2020.

\section{Traumatised Populations}

Another marginalised group unduly affected by COVID-19 is those suffering from various types of trauma. In Kenya, among the traumatised beneficiaries of DIGNITY-supported programmes there were retriggering effects in the form of fear and worsening mental health. Ironically, ameliorative activities were disrupted at a time when need for them increased. Lack of access to services exacerbates risk, reinforcing health precarity. Midrift-Hurinet works on the mental health consequences of violence and trauma. COVID-19 and the anxieties around its management threaten already precarious mental states. At the same time, our CSO partners in Kenya themselves experienced an amplified need of care. Perhaps we all did? Faced with the consequences for their beneficiaries as the crisis took form, they expressed a need for psychological support.

\section{Those With Fragile Livelihoods Dependent on Informal Economies}

The crisis has had long-term consequences for people's well-being and possibilities to earn a living and engage actively in civil society, especially for the most vulnerable groups that have been disproportionally affected. On a societal level, this reinforces inequalities and marginalisation. Labour inequalities and housing inequalities seem particularly significant. Poor people dependent on a hand-tomouth existence through day-to-day hustling in the informal economy have been cut off from opportunities to even scrape together a meagre subsistence by restrictions on transport and movement. Where and how you live matter both in relation to the possibility to meaningfully maintain any form of social distance and the risk of being heavily policed. There was a reported increase in job losses, forced evictions and an increase in infant mortality as many pregnant women's needs were shoved aside to make room for dealing with the increasing COVID-19 threat. Deliberate or not, the crisis involved a rapid reprioritisation with inevitable collateral damage. This is not only the case in South Africa and Kenya but also in the Philippines. Income insecurity, due to restrictions imposed as response to COVID19 , is a key issue facing at-risk populations. DW, a German broadcaster, reports on the struggles facing "dumpster divers" and the plight of those working in the informal economy in the Philippines (Van Brunnersum 2020). They quote Neen Sapalo, a specialist in urban poverty, who makes the important point that in the 
absence of adequate provision of food aid to poor families "the lockdown has only led to worsening poverty and the criminalization of dissent".

In the densely populated neighbourhoods of poor urban settlements in the Philippines characterised by "forced intimacy" (Jensen and Hapal, forthcoming) and small multiple occupancy households, social distancing is a fantasy. Young people live their lives outside. It is practically impossible to be indoors for any extended length of time. Lack of opportunities for children and youth (closed schools, curfews etc.) lead to increased risk-behaviour, frustration and fear-and increased risk of experiencing police brutality. People residing in these neighbourhoods are primarily daily labourers who are deprived of their primary source of income as a result of the COVID-19 lockdowns. The DIGNITY-supported project "Following the Child: Integrated protection of children along their pathway through the juvenile justice and welfare system in the Philippines" addresses children in conflict with the law in the poor urban settlement of Bagong Silang. This group suffers disproportionately during COVID-19, not only because the children - and their families - do not receive sufficient food and basic supplies but also because they have been targeted with violence by law enforcement agents in connection with the lockdown curfew.

Essentially, what we see through our partners' eyes is a situation where existing structures of precarity and vulnerability and existing drivers of violence are reinforced and reproduced. COVID-19 functions as a kind of echo chamber. People with already scarce resources have their possibilities further reduced. In their coverage of a case of police brutality in Uganda, The Guardian reported: "[i]t is one of many African countries where there have been complaints about harsh lockdown enforcement, yet little social protection for citizens who fear they will starve if they can't continue working" (Hayden 2020). Poverty combined with an inability to forge a livelihood under lockdown conditions and inadequate support would seem to perversely invite violence.

\section{Police Brutality}

Journalists and human rights agencies have documented incidents of police brutality in each of the countries with which we are concerned, making explicit links to the COVID-19 situation. The enforcement of curfews and the policing of protest have, in a range of contexts, been done over zealously. Two video reports from Kenya (Kanyi 2020) and South Africa (Miller 2020) are instructive, revealing little novelty about police tactics. ${ }^{4}$ The brutality employed is an extension of standard practices used during unrest or during standard law enforcement procedures targeting marginalised groups. We might speak of the weaponisation of a crisis. Protesters are cognisant of the irony of members of their communities 
being killed in the interests of protecting them from a lethal virus. "It's not corona it's the police killing us", claim the protesters in the BBC video. The COVID-19 situation has not encouraged new forms of policing as much as it has exposed the embeddedness of violence in policing tactics in these countries. It is deep-seated logics that kick in to enhance specific vulnerabilities rooted in historic inequalities and differential spatial geographies. For example, Harrisberg (2020b) reports on how the South African police target low-income black areas under lock down. Poor people in townships were targeted by the police and military and cases of police brutality and torture were reported. When faced with dissent and disorder, the police fall back on standard operating procedures; when presented with opportunities to harass and intimidate marginal groups, there is little hesitation in doing so.

Not surprisingly rights groups were alert to the risk of abuse of emergency powers claimed or legislated for by governments all over the world. While there was acknowledgement that there may well be a certain legitimacy to emergency powers, the concern was with potential overreach, especially in contexts with already highly securitised modes of governance such as those found in Sisi's Egypt (Al Jazeera 2020c) and Duterte's Philippines. In such contexts, the passing of controversial legislation results in much higher levels of suspicion and concern than say in Denmark simply because the stakes are higher, the level of political contestation more intense and the people are used to power being abused. Writing about the Philippines, where the COVID-19 action plan was spearheaded by the military and the police, Robertson (2015) of Human Rights Watch expresses scepticism about the deployment of police and military in waron-drug-style tactics.

In the Philippines curfews in poor urban neighbourhoods have been policed in ways that resemble the policing of the notorious war on drugs. A range of violations has been reported in relation to implementation of quarantine. Violators have been put in cages or forced to sit in the hot sun (Human Rights Watch 2020b). In one case referred to DIGNITY's partner organisation CLRDC by a local NGO based in Manila, seven people - three of them children — who had allegedly violated the curfew were taken into the local police station where their heads were shaved, and some were reportedly beaten. Next morning, they were exhibited to the public as an example, in similar fashion to the way drug users/dealers have been publicly displayed and shamed. Naming and shaming of alleged drug-law violators has been a common practice of late, with detainees sometimes paraded publicly with signs around their necks detailing their offences. The policing of the poor in the Philippines during the pandemic is typically aggressive, applying similar modes of intervention to a new group of offenders and by so doing exhibiting a kind of inherent conservatism. 


\section{Policing of Dissent and Enhanced State-Citizen Distrust}

If South Africa and Kenya teach us about rising levels of precarity at the level of everyday survival, fragile mental health and decreasing levels of trust between citizens and the state, the situation in Egypt and the Philippines where regimes are more authoritarian and aggressive, teach us about the policing of dissent and authoritarian regimes' sensitivity to critique, as well as further illustrating the way the crisis exposes the absence of trust.

In Egypt, even prior to COVID-19, rights violations have been everyday blatant occurrences with few filters and fewer apologies. Activists have been dissatisfied with what is perceived of as a lack of transparency around the COVID-19 situation and for failure to circulate information clearly. The Guardian reports the government's attempt to "control the narrative", citing the prime minister's defensive, doubt-inviting claim: "[w]e announce everything with complete transparency". Lack of trust in the state during this time of crisis seems much in evidence in countries where trust was low in the first place (Michaelson 2020; Al Sherbini 2020).

Complaints from frontline medical practitioners about adequate provisions have featured in many countries. In some countries, complaint is the same as criticism is the same as dissent and is not tolerated. Egypt is such a place. For example, Reuters (2020a) report on a case of doctors detained for speaking out over lack of personal protective equipment (PPE). Speaking truth to power is problematic. Sherif Mansour, representative of the Committee to Protect Journalists, states in this regard "[w]hile some governments worldwide pardon prisoners during the time of COVID-19, Egypt is determined to keep its prisons full of journalists instead of letting them cover the pandemic and other news events freely" (Al Jazeera 2020d). Amnesty (2020a) reports on a similar case, which is a good example of the way freedom of expression limitations are exacerbated by COVID-19.

Duterte's strategy was to militarise the response to the crisis and individualise blame through threats, shaming and deflection of responsibility onto individuals (Al Jazeera 2020e). Troublemakers and people not wearing masks, he stated, risk being shot (Reuters 2020b). Again, these tactics are not new, and this is not a new message from Duterte either. He has suggested shooting to kill as a reasonable tactic to deal with trouble before. It is more symptomatic of Duterte's populist ranting than reflective of a fear that non-mask-wearing might be an expression of organised dissent. Violent crackdowns on dissent/protest/criticism, like those on view in the Philippines (Amnesty 2020b) and Egypt, suggest a pattern of "defensive concealment" (Jefferson and Schmidt 2019) as a protective measure, where it is the state that is protecting itself rather than its citizens. Regime survival is more important than citizen survival. 
If leaders can be thought to somehow embody regimes, then the contrasting styles of leaders are instructive. In contrast to Duterte in the Philippines and Sisi in Egypt, the discourse of Cyril Ramaphosa, president of South Africa, is more hesitant and pragmatic: "[w]e are crossing the river by feeling our way across the stones", he states, "[s]ometimes we put our feet on slippery stones and sometimes on firm ones" (cited in Cocks 2020).

\section{Decarceration and Prisoner Release}

DIGNITY has long had a focus on custodial settings, and our partners in the Philippines and in Egypt (and Uganda) work directly on prison-related issues. Prisons have been quite visible in the international news media in the light of their perceived hot-spot status for COVID-19. In Egypt, while there is no societal level lockdown, there has been a prison lockdown where prisoners' access to the outside world has been cut off and opportunities for external scrutiny through monitoring and inspections curtailed (Committee for Justice 2020). At the time of writing, 33 cases of COVID-19 have been detected in prisons and 13 deaths have occurred. There is little clarity though about what is actually going on in prisons, though we know the situation was dire prior to COVID-19, with common problems being overcrowding, bad hygiene and poor ventilation creating a potentially lethal environment even without the threat of COVID-19. As mentioned, visiting rights were suspended and have not resumed even four months later.

As in many countries, prisoners $(4,000-5,000)$ were released in Egypt but there are questions about the transparency and fairness of the process. A suspicion is that people with connections to government were released while government opponents were not. Questions remain about why pre-trial detainees (innocent until proven guilty) were not considered for release, as was the case in neighbouring Jordan. From a rights perspective this would be an obvious entry point to decongestion. But in some ways the choices of the Egyptian government are no surprise given that pre-trial detention is a form of political repression. ${ }^{5}$

So, while the releases that were made in Egypt are laudable in the sense that they reduce overcrowding and hopefully go some way to reduce the risk of COVID-19 spreading in prison, there is a sense of missed opportunity. Paradoxically even positive moves are made in a twisted manner that feels more like a lost opportunity than a positive outcome to be celebrated and further encouraged. What might have been seized as opportunities to soften the increasingly harsh grip of state power-by tolerating criticism, by listening to a range of opinions, by inviting to share problem-solving - has not materialised.

In Uganda too, the lockdown meant external inspectors and local monitors were unable to carry out their work of scrutiny and holding the state accountable. 
In the Philippines DIGNITY's partner Balay works directly with the prison and jail authorities seeking to prevent torture and ameliorate the worst effects of incarceration. Nearly 22,000 inmates have been released since March (Marquez 2020). The prisons were subject to strict lockdown and closedown to visitors, a practice likely to protect at one level but also subject prisoners to additional hardships given their dependency on visitors for material and moral support. According to human rights reports there has been a lack of transparency around the number of deaths attributable to COVID-19 in Philippine prisons (Human Rights Watch 2020c). The Bureau of Jail Management and Penology (BJMP) reported 1,151 infected detainees by September 10. By June 11, 125 jail personnel across the country had been infected. ${ }^{6}$ Fifteen prisoners have reportedly died from COVID-19. Official statements and inmate accounts don't quite match up. Prison staff report heightened levels of anxiety based, we believe, primarily on long hours and the prohibition on returning home to families between shifts. The BJMP has reached out to Balay, expressing a desire for help and Balay has offered online workshops to help reduce staff tensions.

\section{Changing Configurations and New Opportunities}

We shift now to consider the degree to which COVID-19 separates and isolates or strengthens ties and empowers new alliances. We suggest it can both energise and paralyse, depending on circumstances. Our experience suggests that the crisis might be having some unexpected positive effects on the way civil society organisations relate to one another and how they relate to state institutions.

The global reach of the virus may have subtly changed the conditions of the relationship between DIGNITY and international partners allowing for a different kind of identification with each other. The crisis hit Denmark early and the Danish government was quick to impose a lockdown. While consequences are incomparable, the learning together, as we planned, worked and reprogrammed during the early stages of the crisis, led to a sense of heightened mutuality. We have been reminded that human rights work and torture prevention and rehabilitation are deeply human activities that resist "projectification", streamlining and control. Rather than a "business" project with always clear deliverables and plans to be followed to the letter, the disruption engendered by COVID-19 has reminded us that human rights work should be driven by needs on the ground rather than decontextualised logics and predetermined packages of solutions; solidarity is a precondition of development.

DIGNITY has never been an organisation simply providing resources and technical assistance, and project managers have never simply been distant administrators to whom local partners are formally obliged (through partnership contracts, 
reporting on outcomes and outputs and so on); partnership and relationships have always been important. The crisis has emphasised and enhanced this through the presence of a common set of troubling circumstances around which action and communication have had a heightened intensity. This has taken the form of increased requests for support in the light of the pandemic and a heightened sense of urgency on the part of all parties amid a need to acutely reprogramme activities. While some planned activities could not be carried out - for safety reasons or because they were blocked - new needs emerged that demanded quick and innovative responses. Instead of succumbing to the temptation to define problems in terms of the solutions available, there has been a process of shared diagnosis and mutually determined responsivity to what has felt like a common challenge.

COVID-19 has affected DIGNITY's partners differently. In Egypt it led initially to voluntary self-isolation in the interest of protection, hyper-vigilance and even more obstacles, complications and anxieties associated with the work than normal. Courts were not operating, public officials were unavailable, monitoring of places of detention became tricky. In short, the work became more difficult with very real risk of burn out for activists obliged to work under repressive and claustrophobic conditions. Initially activists were very quiet. They seemed to have gone underground, perhaps preoccupied by local matters. They forgot to share with the outside world. Were they paralysed? No, but they had turned inwards for a time. Like many of our working relationships, DIGNITY's long-standing partnership with human rights defenders in Egypt is built on trust, shared knowledge of each other and a sense that we are engaged in a shared human rights project together. This sense has been enhanced during COVID-19. The North-South relationship is characterised not by capacity building - in the sense of "us" building "their" capacity - but by peer-to-peer interaction.

Our civil society partners have reached out and (surprisingly?) so have state authorities. DIGNITY has sought to be receptive and responsive to local needs. In the Philippines the BJMP has been keen to engage with us (Balay and DIGNITY) both on the implementation of planned project activities as well as new COVID19 related activities. They have engaged in the pre-planned joint development of a psycho-educational training manual for psychologists and other relevant staff on providing psycho-social support to prisoners, and in addition have invited DIGNITY to deliver a webinar on the prevention of COVID-19 in jails. ${ }^{7}$

The crisis changed the conditions facing local CSOs and potentially reconfigured relationships and it has also created new possibilities locally, though not everywhere. States have designed emergency measures on the fly. So have CSOs. CSOs in some contexts have been quick to coordinate and network. In the absence of trust between states and citizens and lack of adequate provision to deal with income insecurity and the like, some communities have taken their own initiatives 
(Laiboni 2020). While there has been increased pressure on community workers, some have seized the initiative and succeeded in providing services against the odds (Bhalla and Wuilbercq 2020). CSOs have thus played a significant role in responses to COVID-19. They have been key actors in reaching the most marginalised people and providing relevant needs-based responses and risk-reducing interventions. In some places they have proved to be more agile than the state authorities based on their local and contextualised understandings of the needs and risks of the population.

For some organisations, reprogramming has involved partnering with the state in COVID-19 preventive responses or at least taking part in a concerted effort. We have seen the credibility of NGOs enhanced in Kenya and South African contexts. In Kenya Midrift-Hurinet has played a role coordinating COVID-19 responses in collaboration with local authorities. In South Africa CSVR responded in parallel with the state. In Uganda, however, COVID responses were coordinated centrally by the government, with little openness for collaboration with CSOs, having the effect of shrinking the civic space even further. Access to prisons to conduct monitoring visits was denied and there was little room for action in the form of reprogramming. Possibilities were restricted or curtailed, and the government took total control of the crisis and initiated measures that cut prisons and prisoners off.

All these examples cast light on the conditions faced by CSOs in the light of the crisis. Some are squeezed and struggle for their existence and to have a voice and space (Egypt, Uganda); others re-tool and adapt (South Africa, Kenya, Philippines) in an agile and opportunistic fashion. Different contexts create different opportunities to collaborate and affect forms of intervention. Recognising the variation in scope conditions and structuring conditions is important. One size does not fit all. COVID-19 impacts people and organisations already trying to help them in different ways. The positive reconfigurations mentioned here are an unexpected bonus. They remind us of the preconditions that frame partnerships and of how these are not entirely fixed but fluid. This bodes well for future work in the nexus between development and humanitarian work.

This leads us to a point where we are ready to think further about the opportunities that have been both seized and missed in the light of the ongoing crisis. What unfulfilled hopes or unfulfilled potentials can we identify? In the light of the article so far, we will briefly flag three areas: global solidarity, penal politics and development politics and alliances.

\section{Global Solidarity or Empathy Retraction?}

The fact that the crisis has been experienced as a threat to all and has caused almost universal disruption reminds us of the commonality of human experience. 
It might seem a crude metaphor but the idea that the virus puts us all in the same boat has some value, if stretched. It is not the same boat we are in. But we are all in a boat. And the seas have suddenly become more tempestuous - for all. In this light, it is possible that the COVID-19 pandemic will serve as a wake-up call to the well-off and the privileged as the world's populations' shared vulnerability is highlighted. But it is also possible that after the initial shock waves settle the plight of the poor and the underprivileged that we documented in the first part of this paper will remain largely ignored. What is certainly the case is that while the virus shows a global reach, we must remain cognizant of the radically inequitable distribution of the negative effects of the virus and responses to it. On the more hopeful side, what we have noted is the way that despite some populations being more at risk than others, being in a situation of threat from the same unpredictable source albeit under different circumstances has created opportunities for comparing experiences and shared/joint learning. These must be consolidated and built upon.

\section{Penal Politics}

Why do states punish and why do they rely so much on imprisonment as the preferred form of punishment? Calls for the decongestion of prisons have been audible for a long time. The COVID-19 crisis triggered decongestion. The mass releases we have seen around the world could, with the help of concerted advocacy, be an excuse to encourage states to rethink their reliance on incarceration in general and pre-trial detention in particular. If prisoners can be released en masse in the face of a crisis, did they really need to be there in the first place? Are high levels of pre-trial detention necessary? It will be possible to look to states (like Jordan) that released high numbers of pre-trial detainees to test whether the arguments for their initial detention really held and challenge the rationale behind justifying its ongoing use. Were they a flight risk? Did the cases against them fail because they were not detained? Where the hand of states has been forced by circumstances to reduce the use of pre-trial detention, might this become a new consolidated practice with positive results? If pre-trial detention can be shown not to be necessary, this would give further impetus for advocacy against its use as a repressive tactic.

In the Philippines a Supreme Court decision led to the release of almost 22,000 prisoners: low-level offenders and members of populations at risk from COVID19 , for example the sick and the elderly. ${ }^{8}$ Such moves allow us to ask, why now? If they did not really need to be there, why keep them there? If these developments could lead to deeper societal questioning about the use and rationale of imprisonment this would be a positive outcome of the crisis. 
Additionally, it is the case that people around the world have been made aware that there is a balance to be maintained between restriction of liberty and protection of rights. People who have never come near a formal site of confinement have experienced in their own bodies some of the pains associated with imprisonment: lack of autonomy, lack of freedom, lack of easy access to goods, lack of mobility, compelled contact with other people in restricted space, compelled lack of contact with loved ones and so on. If there are any signs that this might be transformed into a sense of empathy for imprisoned and at-risk populations these should be seized upon and developed. It is our hope that the crisis can lead to an increased emphasis on decarceration and alternative routes to justice.

\section{Development Politics}

The dynamics around the COVID-19 crisis that we have identified can be understood as part of an emergent political complex pertaining to the pandemic. Old forces and new coalesce. Signs of innovation, new opportunities for CSOs to show their value, reinvigorated alliances and the identification of possibilities for progressive lobbying in the field of criminal justice are encouraging. In this time of crisis, what comes into view quite clearly is the fundamentally relational nature of human rights and development work. Pre-existing relationships and pre-established trust are the foundation on which innovation has been built when it has come to reprogramming on the fly. This is not about the mechanics of protection or the technification of development; this is about its embeddedness in relations and people. Responses to the pandemic remind us that investment in relationships between people and alliances between organisations are crucial. What in developmentspeak is known as technical assistance must be embedded in human peer-peer engagement informed by an ethics of mutual care. The extent to which, in the longer term, restrictions on travel will limit opportunities to be together face-toface in the same space and how this might limit peer-peer interaction deserves serious consideration if what seem like recent gains are not to be relinquished.

\section{Conclusion}

In our introduction we flagged the inherent conservatism of security forces and the agility and responsivity of CSOs. Perhaps, in time, CSOs will become sufficiently innovative and agile to identify even better ways of challenging the embedded and often violent tactics and cultures of states and police forces responding to crises, and even more imaginative ways of encouraging modes of justice that result in reparative healing rather than punitive restriction. We have 
learned that there is great potential for using learnings from the current crisis for better coordination and coherence in the service of rights. To fight the rising tides of authoritarianism and repression and the shrinking of civic spaces as well as the differential effects of the virus, we will need all the agility we can muster. And all hands on deck. It remains an uphill struggle to establish protective grids and deconstruct the toxic dynamics and logics that leave some groups of people apparently less worthy of care than others. The current crisis has helped make visible some of the dynamics through which inequality and injustice are perpetuated. And some of the potentialities that lie in truly working together. We have shown how existing inequalities are reproduced and enhanced. And how they are visibilised in new ways and potentially become less deniable or ignorable. In places where there are glimpses or sparkles of positivity or space in which to manoeuvre, the crisis presents opportunities to rethink certain practices that might otherwise remain taken for granted.

A final thought. In the light of a global crisis we might have hoped for a regeneration of positive human rights values and a reverse of the repressive slide that we have observed in some countries. If only the crisis could be disruptive in a positive direction! Tragically, retrenchment of regressive forces is highly likely, and it will require action and perseverance to keep pushing back. Given this depressing prognosis it is all the more vital to emphasise the inherent value and dignity of all persons and to engage with all the strength we can muster in the struggle to inhibit everyday torture and facilitate protection, all the while seeking to reduce the riskiness of life for those who experience it most harshly.

\section{Notes}

1. Acknowledgements: we thank our international partners (named and un-named in the text) and our colleagues for inspiration and motivation and Hannah Russell for help accessing secondary sources of information. Thanks also to the anonymous reviewer, especially for directing us to the work of Martha Fineman and colleagues on vulnerability. We have not been able to engage with that strand of theorising here, though it looks promising for further illumination of the inherently compromised lives of those with whom DIGNITY work.

2. See for example Turner and Jensen (2019); Weegels et al. (2020); Border Criminologies: www. law.ox.ac.uk; EASA's Anthropology of Confinement Network: www.easaonline.org; and the work of carceral geographers: www.carceralgeography.com.

3. Important insights into colonial governance in Kenya are to be found in Anderson (2005) and Elkins (2005). We imply here that there are links to be made between contemporary repressive policing and the policing of empire in Kenya, that is, there are what Ann Laura Stoler calls "imperial durabilities" (2016). Time does not allow us to elaborate here.

4. See also Al Jazeera (2020b) and Human Rights Watch (2020a).

5. For a chilling report on the use of pre-trial detention as a repressive tactic, see Thabet (2020). 
6. Figures provided by Balay based on news reports.

7. Also worth mentioning is how, with a global audience in mind, DIGNITY's health unit urgently produced a synthesis document, during the early phase of the outbreak, that drew together the various sets of guidelines being developed by a range of professional bodies about how best to protect prisoners (DIGNITY 2020).

8. Of the total 21,858 inmates released, 15,102 were released through bail, plea-bargaining, parole or probation, and 6,756 through acquittal or served sentence.

\section{References}

Al Jazeera (2020a) "Coronavirus pandemic exposes South Africa's "brutal inequality", 12 June. Available online at: www.aljazeera.com/news/2020/06/12/coronavirus-pandemic-exposes-southafricas-brutal-inequality/ (accessed 11 November 2020).

Al Jazeera (2020b) "Kenya: Arrests at: Nairobi protest against police brutality", 7 July. Available online at: www.aljazeera.com/news/2020/07/07/kenya-arrests-at-nairobi-protest-against-policebrutality/ (accessed 11 November 2020).

Al Jazeera (2020c) "Egypt's el-Sisi expands powers, citing coronavirus pandemic", 9 May. Available online at: www.aljazeera.com/news/2020/05/09/egypts-el-sisi-expands-powers-citing-coronaviruspandemic/ (accessed 11 November 2020).

Al Jazeera (2020d) “'Brutal campaign', says press group as Egypt arrests journalist”, 15 May. Available online at: www.aljazeera.com/news/2020/05/15/brutal-campaign-says-press-group-asegypt-arrests-journalist/ (accessed 11 November 2020).

Al Jazeera (2020e) "Duterte threatens arrests, government vows to step up testing", 21 July. Available online at: www.aljazeera.com/news/2020/07/21/duterte-threatens-arrests-government-vows-tostep-up-testing/ (accessed 11 November 2020).

Al Sherbini, R. (2020) "Egypt: Claims about coronavirus outbreak 'rumours", Gulf News, 3 March. Available online at: https://gulfnews.com/world/mena/egypt-claims-about-coronavirus-outbreakrumours-1.70116949 (accessed 11 November 2020).

Amnesty (2020a) "Egypt: Health care workers forced to make impossible choice between 'death or jail”", 18 June. Available online at: www.amnesty.org/en/latest/news/2020/06/egypt-health-careworkers-forced-to-make-impossible-choice-between-death-or-jail/ (accessed 11 November 2020).

Amnesty (2020b) "Philippines: President Duterte gives 'shoot to kill' order amid pandemic response", 2 April. Available online at: www.amnesty.org/en/latest/news/2020/04/philippines-presidentduterte-shoot-to-kill-order-pandemic/ (accessed 11 November 2020).

Anderson, D. (2005) Histories of the Hanged: Britain's Dirty War in Kenya and the End of Empire. New York \& London: W.W. Norton \& Company.

Bhalla, N. and Wuilbercq, E. (2020) "How an Unsung Army of Women Is Waging War on COVID19 in Africa", Global Citizen, 30 June. Available online at: www.globalcitizen.org/en/content/ women-covid-19-community-health-africa/ (accessed 11 November 2020).

Cocks, T. (2020) "South Africa COVID-19 cases surpass 300,000, says health ministry", Reuters, 15 July. Available online at: https://uk.reuters.com/article/us-health-coronavirus-safrica/south-africacovid-19-cases-surpass-300000-says-health-ministry-idUKKCN24G258 (accessed 11 November 2020).

Committee for Justice (2020) "Joint Statement: Egypt: Public Prosecutor And Minister Of Interior Must Disclose Names And Numbers Of Covid-19 Cases In Egyptian Detention Facilities”, 15 
June. Available online at: www.cfjustice.org/egypt-public-prosecutor-and-minister-of-interiormust-disclose-names-and-numbers-of-covid-19-cases-in-egyptian-detention-facilities/ (accessed 11 November 2020).

Crabtree, J. (2020) "South Africa's other pandemic: Femicide rate spikes as coronavirus lockdown lifts", CGTN, 17 July. Available online at: https://news.cgtn.com/news/2020-06-20/South-Africas-femicide-rate-spikes-as-coronavirus-lockdown-lifts-RskMmKKcus/index.html (accessed 11 November 2020).

Devi, S. (2020) "Egyptian health workers arrested after COVID-19 comments", The Lancet World Report, 396 (10248).

DIGNITY (2020) "Synthesis Of Global Guidance And Recommendations On How To Prevent And Manage Covid-19 In Prisons". Available online at: www.dignity.dk/en/publications/\#coviD-19 (accessed 11 November 2020).

Duffield, M. (2001) Global Governance and the New Wars: The Merging of Development and Security. London, New York: Zed Books.

Elkins C. (2005) Britain's Gulag: The Brutal End of Empire in Kenya. New York: Penguin Random House.

Ghoshal, N (2020) "Uganda LGBT Shelter Residents Arrested on COVID-19 Pretext", Human Rights Watch, April 3. Available online at: www.hrw.org/news/2020/04/03/uganda-lgbt-shelter-residentsarrested-covid-19-pretextHumanRightsWatch (accessed 11 November 2020).

Harrisberg, K. (2020a) "Murders of South African Women Surge as 9-Week Lockdown Eases", Global Citizen, 23 June. Available online at: www.globalcitizen.org/en/content/gender-violencecovid-19-lockdown-south-africa/ (accessed 11 November 2020).

Harrisberg, K. (2020b) "South Africans protest police brutality against poor under lockdown”, Reuters, June 9. Available online at: www.reuters.com/article/us-safrica-protests-police-trfn/south-africans-protest-police-brutality-against-poor-under-lockdown-idUSKBN23G2QQ (accessed 11 November 2020).

Hayden, S. (2020) “I realised my body was burning': police brutality in Uganda lockdown", The Guardian, 28 May. Available online at: www.theguardian.com/global-development/2020/may/28/irealised-my-body-was-burning-police-brutality-in-uganda-lockdown (accessed 11 November 2020).

Hodal, K. (2020) "Why coronavirus has placed millions more girls at risk of FGM", The Guardian, 16 June. Available online at: www.theguardian.com/global-development/2020/jun/16/coronavirusmillions-more-girls-risk-fgm (accessed 11 November 2020).

Human Rights Watch (2020a) "Kenya: Police Brutality During Curfew", 22 April. Available online at: www.hrw.org/news/2020/04/22/kenya-police-brutality-during-curfew (accessed 11 November 2020).

Human Rights Watch (2020b) "Philippines: Curfew Violators Abused", 26 March. Available online at: www.hrw.org/news/2020/03/26/philippines-curfew-violators-abused (accessed 11 November 2020).

Human Rights Watch (2020c) "Philippines: Prison Deaths Unreported Amid Pandemic", 28 April. Available online at: www.hrw.org/news/2020/04/28/philippines-prison-deaths-unreported-amidpandemic (accessed 11 November 2020).

Human Rights Watch (2020d) "Egypt: Covid-19 Cover for New Repressive Powers", May 7. Available online at: www.hrw.org/news/2020/05/07/egypt-covid-19-cover-new-repressive-powers. (accessed November 11 2020).

Jefferson, A. M. (2017). "Exacerbating deprivation: trajectories of confinement in Sierra Leone", in Armstrong, R. and Durnescu, L. eds. Parole and Beyond: International Experiences of Life After Prison. London: Palgrave Macmillan. 
Jefferson, A. M. and Schmidt, B. E. (2019) "Concealment and Revelation as Bureaucratic and Ethnographic Practice: Lessons from Tunisian Prisons”, Critique of Anthropology, 39(2): 155-171.

Jensen, S. and Hapal, K. (forthcoming) Communal Intimacy and the Violence of Politics: Understanding the War on Drugs in Bagong Silang, Philippines. Ithaca, New York: Cornell University Press.

Kanyi, E. (2020) "Kenya: Police brutality in the battle against coronavirus in Mathare", BBC, 14 June. Available online at: www.bbc.com/news/av/world-africa-53025934 (accessed 11 November 2020).

Laiboni, N. (2020) "Kenya's Philanthropic Tradition Tackles the COVID-19 Challenge", Chatham House, 9 June. Available online at: www.chathamhouse.org/2020/06/kenyas-philanthropic-tradi tion-tackles-covid-19-challenge (accessed 11 November 2020).

Marquez, C. (2020) "Almost 22K inmates released to decongest jails nationwide", Inquirer.net, 22 July. Available online at: https://newsinfo.inquirer.net/1310151/almost-22000-inmates-releasedto-decongest-jails-nationwide-dilg\#ixzz6dTbxnRZ3 (accessed 11 November 2020).

McCool, A. (2020) “'We were beaten': 20 LGBTQ+ Ugandans file lawsuit over alleged torture”, The Guardian, 22 July. Available online at: www.theguardian.com/global-development/2020/jul/22/wewere-beaten-so-badly-20-lgbtq-people-file-torture-lawsuit-in-uganda (accessed 11 November 2020).

Michaelson, R. (2020) "Egypt: rate of coronavirus cases 'likely to be higher than figures suggest"”, The Guardian, 15 March. Available online at: www.theguardian.com/world/2020/mar/15/egypt-ratecoronavirus-cases-higher-than-figures-suggest (accessed 11 November 2020).

Miller, F. (2020) "South Africa: Security forces accused of fatal lockdown crackdown", Al Jazeera, 10 June. Available online at: www.aljazeera.com/videos/2020/06/10/south-africa-security-forcesaccused-of-fatal-lockdown-crackdown/ (accessed 11 November 2020).

Mogoatlhe, M. (2020) “3 Ways COVID-19 Lockdowns and Curfews Risk Increasing Already Existing Inequalities in Africa", Global Citizen, 2 April. Available online at: www.globalcitizen.org/en/con tent/covid-19-lockdowns-increasing-inequality-in-africa/ (accessed 11 November 2020).

Reuters (2020a) "Some medics say they are muzzled in Egypt's coronavirus response", 29 May. Available online at: www.reuters.com/article/us-health-coronavirus-egypt-medics/some-medics-saythey-are-muzzled-in-egypts-coronavirus-response-idUSKBN2352JX (accessed 11 November 2020).

Reuters (2020b) "Philippines to ramp up coronavirus testing as Duterte warns of arrests", 21 July. Available online at: https:/uk.reuters.com/article/uk-health-coronavirus-philippines/philippinesto-ramp-up-coronavirus-testing-as-duterte-warns-of-arrests-idUKKCN24M0F5 (accessed 11 November 2020).

Robertson, P. (2020) “Philippines Uses 'Drug War' Tactics to Fight Covid-19”, Human Rights Watch, July 15 . Available online at: www.hrw.org/news/2020/07/15/philippines-uses-drug-war-tacticsfight-covid-19 (accessed 11 November 2020).

Stoler, A. L. (2016) Duress: Imperial Durabilities in Our Times, Durham: Duke University Press.

Thabet, M. (2020) "The chilling effect. A study on the use of pre-trial detention as a tool of repression against human rights defenders and activists in Egypt". Euromed Rights. Available online at: www.euromedrights.org/publication/egypt-the-chilling-effect-of-pre-trial-detention-as-a-tool-tosilence-human-rights-defenders/ (accessed 03 December 2020).

Turner, S. and Jensen, S. (2019) Reflections on Life in Ghettos, Camps and Prisons: Stuckness and Confinement. London: Routledge.

Van Brunnersum (2020) "Coronavirus: Vulnerable Filipinos fight for survival during lockdown", Deutsche Welle (DW), 27 April. Available online at: www.dw.com/en/coronavirus-vulnerablefilipinos-fight-for-survival-during-lockdown/a-53258915 (accessed 11 November 2020).

Weegels, J., Jefferson, A. M., and Martin, T. M. (2020) "Introduction: Confinement Beyond Site: Connecting Urban and Prison Ethnographies”, Cambridge Journal of Anthropology, 38(1): 1-14. 